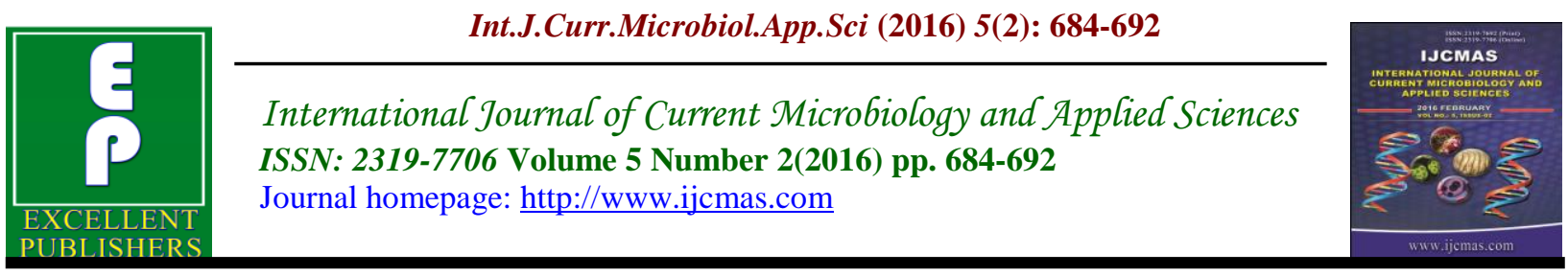

Original Research Article

doi: http://dx.doi.org/10.20546/ijcmas.2016.502.075

\title{
Preliminary Physicochemical and Microbiological Analysis of Bahini River Water of Guwahati, Assam, India
}

\author{
Shally Sultana Choudhury ${ }^{1}$, Ajay Keot ${ }^{1}$, Hiramoni Das ${ }^{1}$, Mukutamoni Das ${ }^{1}$, \\ Chinmoy Baishya ${ }^{1}$, Aniruddha Sarma ${ }^{1}$ and Parag Deka ${ }^{2}$
}

${ }^{1}$ Department of Biotechnology, Pandu College, Maligaon-781012, Assam, India

${ }^{2}$ Department of Zoology, Pandu College, Maligaon-781012, Assam, India

*Corresponding author

\begin{abstract}
A B S T R A C T
Keywords

Physicochemical analysis, Microbiological Analysis, Bahini River, MPN, Water

Article Info

Accepted: 29 January 2016 Available Online: 10, February 2016

In this study, the physicochemical and microbiological examination of Bahini River was carried out to ascertain their suitability for consumption and presence of microorganisms that could cause water-borne diseases. The water sample was collected from four different sites of the river based on their use by the local people. A total of 10 replications were taken for each site. The results obtained were compared with WHO and EPA standards for drinking and recreational water. With the exception of TSS, Total alkalinity, total acidity and BOD, all others were within the standards set for $\mathrm{pH}$, Total Dissolved Solids, Chloride, Total Hardness, Nitrate, Iron, DO and COD. Though the total hardness were much below the WHO permissible limit, it was found to be a little higher near ISBT and Gorchuk area ( $95 \pm 8.66$ and $50 \pm 0$ respectively). In the microbiological analysis, the Total Viable Count for all the sites were found to be very high. Coliform group of bacteria are differentiated by the presumptive test, confirmed test and completed test. From the test, the MPN index of the water sample were also found to be very high for all the three replicates for all the four sites under study. After performing these tests Gram negative, were non spore forming and rod shaped bacteria having metallic sheen or pink with dark centered colonies on EMB agar indicated positive results. The isolates were characterized and identified as E. coli, Bacillus sp., Enterobacter sp., Klebsiella sp. and Pseudomonas sp. Thus, the study suggests that the river water needs urgent measures to control pollution and also to aware the local people to properly treat the water before using.
\end{abstract}

\section{Introduction}

Water is an important natural resource on earth. It is necessary for all living organisms, ecological system, human health, food production and economic development (Shafiq et al., 2013). Water can be obtained from a number of sources, among which are streams, lakes, rivers, ponds, rain, springs, and wells (Okonko et al., 2008). The ensuring of good quality drinking water is a basic factor in guaranteeing public health, the protection of environment and sustainable development (Rajini et al., 2010). Good quality drinking water is of basic importance to human physiology and 
man's continued existence depends very much on its availability (Lemikanra, 1999; FAO,1997). Urbanization has direct impact on water bodies as the settlement takes place around the vicinity of water bodies causing encroachment near water bodies (Pavendan et al.,2011). People obtain their consumable water from surface and ground water. However, both surface and ground water sources could become polluted by biological and chemical contaminants arising from point and non-point sources (Shafiq et al., 2013). Surface water is polluted as high levels of nutrients (Nitrogen and Phosphorus) cause eutrophication, leading to the growth of other microorganisms and causes contamination in surface water. Other contamination sources of surface water are household wastes, sewage water, industrial effluent, synthetic detergents, agrochemical, oil spillage, etc.(Kaushik and Kaushik, 2012; Geldreich, 1990). The most dangerous form of water pollution occur when fecal contaminant like Escherichia coli enter in water supply. Contaminants ingested into water supply causes many diseases. Examples of such pathogens are Salmonella spp., Shigella spp, Vibrio cholera and E.coli (Smruti and Sanjeeda, 2012 ). The transmission of disease through drinking water is one of the primary concerns for a safe drinking water. Fecal pollution of drinking water may introduce a variety of intestinal pathogens which may cause disease from mild gastro-enteritis to severe and sometimes fatal dysentery, diarrhoea, cholera, typhoid, hepatitis, giardiasis etc.(Crown, 1986; Wanda, 2006). Therefore, potable water is tested for an indicator of human or animal waste known as coliform bacteria. Ideally drinking water should be free from pathogenic microorganism and free from bacteria indicative of fecal pollution (FEPA, 1999). The E.coli and fecal coliforms may come either by fecal materials of human or other warm-blooded animals (Ayaz et al., 2013). According to U. S. Environmental Protection Agency (EPA), E. coli is a good indicator of fecal pollution than fecal coliform to evaluate fresh water quality.

The bacteriological quality of drinking water is of paramount importance and monitoring must be given priority (Bharti and Katyal, 2011). Water pollution results in transmission of infectious diseases such as dysentery, cholera, diarrhoea, typhoid, shigellosis, salmonellosis, and varieties of other bacterial as well as fungal, viral, and parasitic infection (Nwachukwu and Ume, 2013). Some water born life threatening diseases are also reported like cancer, hepatitis etc. because of certain highly toxic heavy metals in water like, arsenic, nitrate etc.( Ayaz et al., 2013). World Health Organization informed that contaminated water, inadequate sanitation and poor hygiene cause over $80 \%$ of disease in developing countries (WHO, 1998). Before water can be described as potable, it has to comply with certain physical, chemical and microbiological standards, which are designed to ensure that the water is potable and safe for drinking (Tebutt, 1983). Potable water is defined as the water that is free from disease producing microorganisms and chemical substances deleterious to health (Ihekoronye and Ngoddy, 1985). Water is a good solvent and picks up impurities easily. Pure water is tasteless, colorless, and often called the universal solvents (Pavendan et al., 2011). Conformation with physiological and microbiological standards is of special interest because of the capacity of water to spread disease within a large population. Although the standards vary from place to place, the objective anywhere is to reduce the possibility of spreading water born disease (Edama et al. 2001). Bathing, and swimming in streams and river are also common among children and adults in the 
local community. The probability of ingesting infective dose of disease causing microorganism is very high considering the fact that water borne pathogens generally have low infective dose (Shittu et al., 2008).

\section{Brief Description of the Study Area}

Originating in the northern slope of Meghalaya plateau, Bahini river has its source at 460 meters height from mean sea level at Mylliem reserved forest ( $\mathrm{Ri}$ Bhoi district, Meghalaya) and merges with the Deepor Beel (Kamrup Metro district, Assam). The Bahini river flowing through the Guwahati city (from Basistha temple through Hatigaon-Bhetapara through ISBT, Gorchuk) ultimately flows into the wellknown Deepor Beel (Planning Commission, Govt. of India, 2008). The river water is seen to be extensively used by the local people for their daily work including drinking, cooking, bathing, washing etc. all along the Bahini River at different locations. The river water is also used for puja purpose of the temple. Fishing in river is also very common. Many cultural and social activities are usually performed at the bank of river at different places. The river is also exposed to industrial pollutants near Gorchuk area.

The main aim of the study was to investigate the water sample from four different sites [Basistha temple (site 1), Bhetapara (site 2), ISBT(site 3) and Gorchuk(site 4)] of the river for their physicochemical and microbiological parameters which may provide us valuable information about the extent of pollution that this water body is facing. The sites were selected based on their use by local people.

\section{Materials and Methods}

\section{Sample Collection}

The study was conducted during February to April before the onset of monsoon. Water samples were collected for both physiochemical and microbiological analysis aseptically in sterile bottles during morning hours between 9:30 to 10:00 am. The sterile bottles were opened at the time of sample collection and brought to the laboratory for analysis within 1 hour. Separate samples were collected for BOD and DO experiments in BOD bottles and preferably sample was collected after $3 \mathrm{pm}$. The bottle with the cap was immersed in the water after which the cap was opened and water was allowed to enter without bubbling. Tests were performed within 6 hours of collection. The samples were collected from four sites which had maximum human activities each having ten replications.

\section{Physicochemical Analysis}

The physicochemical tests included the $\mathrm{pH}$, Total Dissolved Solids, Total Suspended Solids, Total Alkalinity, Total Acidity, Chloride, Total Hardness, Nitrate, Iron, DO, $\mathrm{BOD}_{3}, \mathrm{COD}$ which were determined by the methods of APHA (1998) standard, EPA (2003) and FAO (1997). pH was determined by a digital $\mathrm{pH}$ meter MKVI, Systronics while temperature was measured using a thermometer, Hicks make, whose range was between $0-150^{\circ} \mathrm{C}$.

\section{Microbiological Analysis}

The microbiological analysis was carried out by the methods described by Cappuccino and Shermen (2005). The most probable number (MPN) - multiple tube technique was used for coliform enumeration. Nutrient Agar and Eosin Methylene Blue Agar were used to determine the total viable count and for detection of coliforms respectively. All plates were incubated at $35^{\circ} \mathrm{C}$ for 24 hours. Presumptive colonies were confirmed by gram staining and biochemical test reactions. 


\section{Results and Discussion}

The physicochemical analysis of the sample water is presented in Table 1. Analysis showed that the water quality parameters were within the normal permissible limits, except a few parameters. During the experimental period (February to March,2015), it was observed that $\mathrm{pH}$ ranged between 6.8-7.6 for all the sites, which is slightly acidic to slightly alkaline, which comply with the WHO (2011) standard (6.8-8.5). The $\mathrm{pH}$ of water is very important in that changes in $\mathrm{pH}$ values may affect the toxicity of microbial poisons in the water (Okonko et al., 2008). In the present study, $\mathrm{pH}$ near neutrality of the water sample poses no health risk to consumers who use the water for cooking, drinking, washing, bathing etc. Acidic $\mathrm{pH}$ observed may be an indication of the contamination of the water sample (Okoreke et al., 2014) .

Temperature varied between $23-24{ }^{0} \mathrm{C}$ which lie within the range of $<32^{\circ} \mathrm{C}$ for safe drinking water (WHO, 2011). The temperature range observed in this work will discourage the rate of chemical and biochemical reactions, solubility of gases in the water which could impact negativity on the taste and odour of the water at higher temperatures (Ayoko et al., 2007). The present observation is contradictory to the result obtained by Mgbemena and Okwunodulu, (2015) who reported that the average temperature was between $28-29^{\circ} \mathrm{C}$.

Total dissolved solids (TDS) comprises inorganic salts and small amount of organic matter that dissolved in water (WHO, 2011). In the present study, the total dissolved solids (TDS) was found to be $116.67 \pm 28.86$ $\mathrm{mg} / \mathrm{l}, \quad 238.89 \pm 34.69 \quad 472.20 \pm 25.46 \mathrm{mg} / \mathrm{l}$, $272.22 \pm 25.46 \mathrm{mg} / \mathrm{l}$ in water samples of site $1,2,3$ and 4 respectively, which falls within normal range as described by WHO i.e. $1000 \mathrm{mg} / \mathrm{l}$ for drinking water (WHO, 2011).

The total suspended solids(TSS) value obtained was 183.33 $\pm 28.86 \mathrm{mg} / \mathrm{l}$, $316.66 \pm 28.86 \mathrm{mg} / \mathrm{l}, \quad 544.57 \pm 50.87 \mathrm{mg} / \mathrm{l}$, $305.57 \pm 58.53 \mathrm{mg} / \mathrm{l}$ at sites $1,2,3,4$ respectively, which exceeds the normal range as described by WHO for drinking water standards (Okereke et al., 2014). The suspended solids are insoluble particles that either float on water or are in suspension causing turbidity (Sammori et al., 2004). Though the values of total suspended solids obtained in this work is relatively higher than the limit of WHO (2011), it might support the growth of bacteria and favor biofilm formation since suspended solids acts as points of attachment for bacteria.

In the present study, the total alkalinity of water sample was found to be very less $26.66 \pm 0.57 \mathrm{mg} / 1, \quad 30.67 \pm 0.57 \mathrm{mg} / 1, \quad 26 \pm 0$ $\mathrm{mg} / \mathrm{l}, 51 \pm 0 \mathrm{mg} / \mathrm{l}$ at sites $1,2,3$ and 4 respectively. According to WHO standard, the highest desirable limit (HDL) and maximum permissible limit (MPL) for the total alkalinity is $200-600 \mathrm{mg} / \mathrm{l}$ (Khare et al., 2011). The acidity of water sample was found to be $10.66 \pm 0.57 \mathrm{mg} / \mathrm{l}, 25 \pm 1.73 \mathrm{mg} / \mathrm{l}$, $25 \pm 0 \mathrm{mg} / \mathrm{l}, 31 \pm 0 \mathrm{mg} / \mathrm{l}$ in the water samples of the four sites respectively. The values are very much within the permissible limits of WHO, 2011.

The present study shows that the total hardness of water sample was $23.33 \pm 2.88 \mathrm{mg} / 1$ for site 1 and 2 , whereas site 3 has $95 \pm 8.66 \mathrm{mg} / \mathrm{l}$, and site 4 has $50 \pm 0$ $\mathrm{mg} / \mathrm{l}$. The increase in hardness for site 3 may be due to the proximity of industry which discharges its effluent into the water body. The results are similar to those of Sunday et al., 2012. The total hardness (the sum of calcium and magnesium ions ) of samples were less than $500 \mathrm{mg} / \mathrm{l}$ and within 
the permissible limit of WHO suggesting that the water is soft and fit for domestic use (Godwill et al., 2015).

The chloride concentration of water was found to be $8.32 \pm 2.87 \mathrm{mg} / \mathrm{l}, 13.32 \pm 2.89$ $\mathrm{mg} / \mathrm{l}, 31.65 \pm 2.88 \mathrm{mg} / \mathrm{l}, 56.64 \pm 2.88 \mathrm{mg} / \mathrm{l}$, which is similar to the result obtained by Okereke et al.(2014). Excessive chloride concentration increases rates of corrosion of metals. Chloride is one of the major anion in water, it is generally associated with sodium. High level of chloride ions may result in an objectionably salty taste (WHO, 2011).

The nitrate content of the water is between $0.0-0.346 \mathrm{mg} / \mathrm{l}$ which is considerably low and poses no health risk to consumers. High Nitrate content in the presence of microbial contamination can lead to cyanosis disease or blue baby syndrome in bottle fed infants (WHO, 2011), thus nitrate levels above 100 $\mathrm{mg} / \mathrm{l}$ is not recommended for use in infants. Nitrate is found naturally in the environment and it is an important plant nutrient. The nitrate level observed in this work show that there is less exposure of water to inorganic constituents within the aquiferous material, and this pose no health risk to consumer as the nitrate level is within the standard for drinking water.

The iron concentration in sample water was not detected at site 1 whereas in other sites it was very low. This result is in agreement with Okereke et al. (2014) indicating that water is suitable for domestic or drinking purpose in this aspect and poses no health risk. The EPA standard for iron for drinking water is $0.3 \mathrm{mg} / \mathrm{l}$ ( EPA, 1995). Iron, when present in high detectable amounts can affect the flavor of tea, coffee and alcoholic beverages. It can also promote the growth of iron bacteria in water and also makes the water distasteful (Yagoub and Ahmed, 2009).
Dissolved Oxygen in the present study was found to be between $7.06 \pm 1.15 \mathrm{mg} / \mathrm{l}$ to $11.46 \pm 0.46 \mathrm{mg} / \mathrm{l}$.Potable water should contain at least $5 \mathrm{mg} / 1$ of DO (Obodo, 2002). This indicates that the sample water has normal DO. Dissolved Oxygen is an important measure of the extent of pollution, the lower its value, the higher the pollution concentration and vice versa (Mgbemena and Okwunodulu, 2015).

Biological Oxygen Demand (BOD) measures the amount of oxygen used by microorganisms, in this case bacterium, to oxidize organic matter present within the samples (Neilson, 2004). Water samples with the BOD less than $4.0 \mathrm{mg} / \mathrm{l}$ are considered clean. From the table, the BOD ranges from $10.8-21.6 \pm 0.01 \mathrm{mg} / \mathrm{l}$. This means that water is not clean (Rajini et al., 2010).

According to Rajini et al.,(2010), the WHO standard for COD of good quality water is $<10 \mathrm{mg} / \mathrm{l}$. If the COD is higher it will contain greater number of micro-organisms .COD is a measure of the capacity of water to consume oxygen during the decomposition of inorganic chemicals such as nitrate and ammonia. The COD is related to BOD. However, BOD only measures the amount of oxygen consumed by microbial oxidation and is most relevant to water rich in organic matter (Franson, 1975).

The COD of our sample was found to be 6.4 $\mathrm{mg} / \mathrm{l}$ and $9.8 \pm 0.69$ at site 1 and site 2 , which is normal. This makes the river water at these sites suitable for domestic purpose (Sunday et al., 2012). But at site 3 and 4, it exceeded the WHO permissible limit, it was found to be $15.01 \pm 0.026 \mathrm{mg} / \mathrm{l}$ and $11.62 \pm 0.40 \mathrm{mg} / \mathrm{l}$. Thus water from these sites cannot be used for domestic purposes. 
Table.1 The Physico-Chemical Properties of Bahini River

\begin{tabular}{|l|l|l|l|l|l|l|}
\hline Sl.No. & Parameter & Site 1 & Site 2 & Site 3 & Site 4 & $\begin{array}{l}\text { WHOpermissible } \\
\text { limits }\end{array}$ \\
\hline 1. & $\mathrm{pH}$ & $6.8-7.2$ & $7.4-7.6$ & $6.8-7.2$ & $7.0-7.2$. & $6.5-8.5$ \\
\hline 2. & Temperature & $23-24^{\circ} \mathrm{C}$ & $23-24^{\circ} \mathrm{C}$ & $23-24^{\circ} \mathrm{C}$ & $23-24^{\circ} \mathrm{C}$ & $<32$ \\
\hline 3. & TDS $(\mathrm{mg} / \mathrm{l})$ & $116.67 \pm 28.86$ & $238.89 \pm 34.69$ & $472.20 \pm 25.46$ & $272.22 \pm 25.46$ & 1000 \\
\hline 4. & TSS (mg/l) & $\begin{array}{l}183.33 \pm \\
28.86\end{array}$ & $316.66 \pm 28.86$ & $544.57 \pm 50.87$ & $305.57 \pm 58.53$ & 100 \\
\hline 5. & $\begin{array}{l}\text { Total Alkalinity } \\
(\mathrm{mg} / \mathrm{l})\end{array}$ & $26.66 \pm 0.57$ & $30.67 \pm 0.57$ & $26 \pm 0$ & $51 \pm 0$ & \\
\hline 6. & $\begin{array}{l}\text { Total Acidity } \\
(\mathrm{mg} / \mathrm{l})\end{array}$ & $10.66 \pm 0.57$ & $25 \pm 1.73$ & $25 \pm 0$ & $31 \pm 0$ & $4.5-8.2$ \\
\hline 7. & Chloride (mg/l) & $8.32 \pm 2.87$ & $13.32 \pm 2.89$ & $31.65 \pm 2.88$ & $56.64 \pm 2.88$ & 250 \\
\hline 8. & $\begin{array}{l}\text { Total Hardness } \\
(\mathrm{mg} / \mathrm{l})\end{array}$ & $23.33 \pm 2.88$ & $23.33 \pm 2.89$ & $95 \pm 8.66$ & $50 \pm 0$ & 200 \\
\hline 9. & Nitrate $(\mathrm{mg} / \mathrm{l})$ & Undetectable & $0.287 \pm .005$ & $0.346 \pm .005$ & $0.223 \pm 0.005$ & 50 \\
\hline 10. & Iron $(\mathrm{mg} / \mathrm{l})$ & Undetectable & $0.023 \pm .005$ & $0.026 \pm .005$ & $0.022 \pm 0.005$ & 0.3 \\
\hline 11. & $\begin{array}{l}\text { Dissolved Oxygen } \\
(\mathrm{mg} / \mathrm{l})\end{array}$ & $7.06 \pm 1.15$ & $11.46 \pm 0.46$ & $6.13 \pm 0.46$ & $5.867 \pm 0.46$ & $>5$ \\
\hline 12. & BOD $(\mathrm{mg} / \mathrm{l})$ & 10.8 & $21.6 \pm .01$ & $19.2 \pm 0.1$ & $17.6 \pm 0.1$ & $<4$ \\
\hline 13. & COD(mg/l) & 6.4 & $9.8 \pm 0.69$ & $15.01 \pm 0.026$ & $11.62 \pm 0.40$ & $<10$ \\
\hline
\end{tabular}

Site 1-4: Basistha temple, Bhetapara, ISBT and Gorchuk.

Values represented in the table are mean \pm S.D

Table.2 Microbiological Analysis

\begin{tabular}{|l|l|l|l|l|l|}
\hline Sl.No. & & Site 1 & Site 2 & Site 3 & Site 4 \\
\hline 1. & Total Viable Count & $23 \times 10^{4} \mathrm{cfu} / \mathrm{ml}$ & $33 \times 10^{4} \mathrm{cfu} / \mathrm{ml}$ & $46 \times 10^{4} \mathrm{cfu} / \mathrm{ml}$ & $23 \times 10^{4} \mathrm{cfu} / \mathrm{ml}$ \\
\hline 2. & MPN $/ 100 \mathrm{ml}$ & $\geq 2400 / 100 \mathrm{ml}$ & $\geq 2400 / 100 \mathrm{ml}$ & $\geq 2400 / 100 \mathrm{ml}$ & $\geq 2400 / 100 \mathrm{ml}$ \\
\hline
\end{tabular}

Site 1-4: Basistha temple, Bhetapara, ISBT and Gorchuk.

\section{Micro-biological Analysis}

Most coli forms are present in large numbers among intestinal flora of humans and other warm blooded animals, and thus found in fecal wastes (Dorothy, 1998). As a consequence, coliforms detected in higher concentrations than pathogenic bacteria, are used as an index of the potential presence of entero-pathogens in water environments (Rompre, 2002). Coliforms are also routinely found in diversified natural environments, some of them are of telluric origin, but drinking water is not a natural environment for them. As a result, their presence in drinking water must be considered as harm to human health. Positive presence of coliforms in treated water which is usually coliform-free may indicate treatment ineffectiveness.

The three basic tests-the presumptive, confirmatory and completed test were done to determine the quality of water samples. From the test, the MPN index of the water sample were found to be $\geq 2400 / 100 \mathrm{ml}$ for all the three replicates with $95 \%$ probability limit more than 700, for all the four sites under study. The coliform count for the samples were exceedingly high as the EPA 
(Environment Protection Agency) maximum contamination level for coliform bacteria in drinking water is zero coliform per $100 \mathrm{ml}$ water(EPA, 2003). The high coliform count obtained in the present study may be an indication that the water sources are fecally contaminated (Osuinde and Enuezie, 1999). The Total Viable Count for site 1 was found to be $23 \times 10^{4} \mathrm{cfu} / \mathrm{ml}$, for site 2 was $33 \times 10^{4} \mathrm{cfu} / \mathrm{ml}$, for site 3 was $46 \times 10^{4} \mathrm{cfu} / \mathrm{ml}$, and for site 4 was $23 \times 10^{4} \mathrm{cfu} / \mathrm{ml}$. Thus, total Viable Counts in all the sites were high which indicates that the presence of bushes and shrubs around water bodies makes it likely possible that some individuals may have been coming around to drink water thereby passing out faeces into the stream water. High TVC for site 3 might be due to the proximity of the site to industry. Further biochemical tests were done for some selected colonies which revealed the presence of E. coli, Bacillus sp., Enterobacter sp., Klebsiella sp. and Pseudomonas sp. Similar results have also been obtained by Edama et al.,2001.

This study concluded that the Bahini River needs a serious effort in limiting the numbers of microorganisms released into the body. The high microbial load in the river renders it to be unfit for human consumption though they can be used for other purposes. Water should meet different quality specifications depending on the particular uses. Potable and domestic water should be harmless for human health and other domestic uses (Rajini et al., 2010; Okonko et al., 2008). Though the Government of Assam has taken steps to clean the banks of all the water bodies in Guwahati and also fencing of the river banks to prevent human and animals from misusing, but still the river bodies could not be cleaned up as the local people break up the fences to meet their daily needs. Thus, the water body needs urgent measures to control pollution by controlling human activities to prevent sewage from entering the water body which is the key to avoid bacterial contamination of the water, and thus provide means of safe water for use, thereby protecting the water body. Programmes must be organized to educate the general populace on the proper disposal of refuse, treatment of sewage and need to purify the water to make it fit for use because the associable organisms are of public health significance being implicated in one form or the other. Educative programmes must be organized by the researchers and government agencies to enlighten the dwellers of the area on the proper use of surface water.

\section{Acknowledgement}

The authors are grateful to the Principal, Pandu College and Institutional Biotech Hub, Pandu College for the lab facilities to carry out the experiment.

\section{References}

APHA. (1998) Standard Methods for examination of water and waste water $\left(20^{\text {th }}\right.$ Ed., pp 81-85). American Public Health Association, New York

Ayaz.A; Jauhar.S; Farman.U; Waheed.U; Zia U; Nawab.A. (2013), Biochemical and microbiological evaluation of the water samples collected from different areas of district Kohat and Mohamand Agency, Pakistan. Pure Appl. Bio., 2(3): 96-103.

Ayoko. A. (2007) Exploratory Multivariate modeling and prediction of the physicochemical properties of surface water and ground water. J. Hydro., 336:115- 124.

Bharti N. and Katyal D. (2011). Water quality indices used for surface water vulnerability assessment, Inter. J. Envir. 
Sci., 2(1) : 154.

Cappuccino.J.C and Sherman.N: .(2005) Experiment 51; Standard Qualitative Analysis of Water. In Microbiology A Laboratory Manual. Pearson: 323-327.

Crown, G. F. 1986.Water-borne Diseases in the United States. CRC Press, Inc.

Dorothy, A.G. and R.A. Philip. 1998. Technology of Bottled Water. USA: Sheffield Academic Press.

Edama M.D; Omemu A.M; Fapetu O.M. (2001). Microbiological and physicochemical analysis of different sources of drinking water in Abeokuta, Nigeria. Niger J. Microbial 15(1):5761.

EPA. (2003) US Environmental Protection Agency Safe Drinking Water Act. EPA 816-F-03-016.

Federal Environmental Protection Agency (FEPA) 1999: Federal Republic of Nigeria Proposed National Water Quality Standards.

Food and Agriculture Organization (FAO)(1997)Chemical analysis manual for food and water. J. Agric Food Chemical, 1(2):20-26

Franson, M.A.. (1975)Standard Methods for the Examination of Water and Waste Water. $14^{\text {th }}$ ed., APHA-AWWA- WPCF, APHA Publication office, $1011518^{\text {th }} \mathrm{St}$. NW, Washington DC, 20036 PP. 185237, 301-392, 405- 489.

Geldreich, E.E. (1990). Microbiological Quality of Source Waters for Water Supply. In: Mc Feters, G.A. (Ed.), Drinking Water Microbiology. Springer-Verlag, New York, pp: 3-31.

Godwill. E.A; Richard.T.A; Junior L.C.P.; (2015) Marcellus: Physicochemical and microbial analysis of portable water sources in Enugu metropolis. Journal of Public Health and Epidemiology, 7(3).65-70.

Ihekoronye A. I. and Ngoddy P.O. 1985 Integrated Food Sciences and
Technology for the Tropics. Macmillan Press, London, Oxford, pp 95-195.

Kaushik.A and Kaushik.C.P.: (2008) Water Pollution: Perspectives in Environmental Studies: New age International publishers, p.155.

Khare R. and Khare, S. (2011) Physicochemical analysis of Ganga Water, Asian journal of biochemical and pharmaceutical Research, 1(2).

Lamikanra, A. (1999) In: Essential Microbiology for students and practitioner of Pharmacy: Medicine and Microbiology, 2nded. Lagos: Amkra books, p.406.

Mgbemena N. M and Okwunodulu F. U.; (2015) Physicochemical and microbiological assessment of borehole waters inUmudike, Ikwuano L. G. A., Abia State, Nigeria. Advances in Applied Science Research.6 (4):210214.

Nwachukwu, E., \& Ume, C. A. , (2013)Bacteriological and physicochemical qualities of drinking water sources in local area of Eastern Nigeria. J. Environ. Sci. Water Res., 2(9), $336-341$.

Obodo, G.A. (2002) Pollution Estimates of Rivers Nworie, Otamiri, Imo, Aba and Mbaa. Journal of Physical Sciences, 1(1), 27.

Okereke, V. E ,Ogwo, P. A , Okoronkwo, C. U., and Udensi, E. A. (2014) Evaluation of the Physicochemical and Heavy Metal Properties of Igwi-Stream in Abia State University, Uturu, Abia State, Nigeria. IOSR Journal of Environmental Science, Toxicology and Food Technology (IOSR-JESTFT) 8(7): 54-57.

Okonko,I.O; Adejoje, O.D; Ogunnusi, T.A; Fajobi, E; Shittu, O.B. (2008). Microbiological and physicochemical analysis of different water samples used for domestic purposes in Abeokuta and 
Ojota, Lagos Nigeria. African $J$. Biotechnol, 7(5) 6717-6721.

Osuinde. M.I. and Eneuzie, N.R.. (1999)Bacteriological analysis of ground water. Nigeria Journal of Microbiology 13: 47-54. Pavendan P; Selvan.A.S and

Rajasekaran.S.C.(2011).Physico

Chemical and microbial assessment of drinking water from different water sources of Tiruchirappalli District, South India. European Journal of Experimental Biology, 1(1) 183-189.

Planning Commission, Government of India. (2008) Report on Visit to DeeporBeel in Assam - a wetland included under National Wetland Conservation and Management Programme of the Ministry of Environment \& Forests.

Rajini K; Roland P; John C; Vincent R. (2010)Microbiological and physicochemical analysis of drinking water in George town. Nature and Science, 8 (8)261-265.

Rompré, A., P. Servais, J. Baudart, M.deRoubin, andP.Laurent. (2002) Detection and enumeration of coliforms in drinking water: current methods and emerging approaches. Journal of Microbiological Method. 49 : 31-54.

Sammori T, Zulkifli Yusop, Baharuddin Kasran, Shoji Noguchi and Makoto Tani. (2004) Suspended solids discharged from small forested basin in humid tropics. Hydro. Proc., 18 (4): 721 -738 .

Shafiq A; Ayaz A; Ihteram U; Nadia N; Ammar A; Nawab A. (2013).
Bacteriological and Biochemical Evaluation of the Springs water of district Buner, Khyber Pakhtunkhwa, Pakistan. International Journal of Advancements in Research \&Technology, 2 (7) 452-460.

Shittu, O.B., Olaitan, J.O. and Amusa, T.S. (2008). Physico-Chemical and Bacteriological Analyses of Water Used for Drinking and Swimming Purposes in Abeokuta, Nigeria. African Journal of Biomedical Research, 11: 285-290.

Smruti.S and Sanjeeda.I. (2012): Microbiological analysis of surface water in Indore, India. Research Journal of Recent Sciences, 1: 323-325.

Sunday.O.E. and Innocent. C.M. (2012): Physicochemical and Microbiological analysis of water bodies in Uturu, Abia State - Nigeria.

Tebutt, T. H. Y. (1983) In Principles of Quality Control. Pergamon, England. Pg 235.

WHO (2011) Guidelines for drinking water quality $\left(4^{\text {th }}\right.$ Ed.), Acceptability aspects: taste, odour and appearance. Geneva, 1294

WHO. (1998). Guidelines for drinking water quality $\left(2^{\text {nd }}\right.$ Ed.). Health criteria and other supporting information, Geneva, 2:9400-9491.

Yagoub,A.E.A and Ahmed, T.A. (2009). Microbiological evaluation of the quality of tap water distributed at Khartoum State. Research Journal of Microbiology. 4(10): 355-360.

\section{How to cite this article:}

Shally Sultana Choudhury, Ajay Keot, Hiramoni Das, Mukutamoni Das, Chinmoy Baishya, Aniruddha Sarma and Parag Deka. 2016. Preliminary Physicochemical and Microbiological Analysis of Bahini River Water of Guwahati, Assam, India. Int.J.Curr.Microbiol.App.Sci.5(2): 684-692. doi: http://dx.doi.org/10.20546/ijcmas.2016.502.075 